University of Florida Levin College of Law

UF Law Scholarship Repository

UF Law Faculty Publications

Faculty Scholarship

2020

After Forty Years of Antitrust Revision and Apple v. Pepper, What

Now Illinois Brick?

Jeffrey L. Harrison

University of Florida Levin College of Law, harrisonj@law.ufl.edu

Follow this and additional works at: https://scholarship.law.ufl.edu/facultypub

Part of the Antitrust and Trade Regulation Commons

Recommended Citation

Jeffrey L. Harrison, After Forty Years of Antitrust Revision and Apple Inc. v. Pepper, What Now Illinois Brick?, 11 Wm. \& Mary Bus. L. Rev. 695 (2020)

This Article is brought to you for free and open access by the Faculty Scholarship at UF Law Scholarship Repository. It has been accepted for inclusion in UF Law Faculty Publications by an authorized administrator of UF Law Scholarship Repository. For more information, please contact kaleita@law.ufl.edu. 


\title{
AFTER FORTY YEARS OF ANTITRUST REVISION AND APPLE INC. V. PEPPER, WHAT NOW ILLINOIS BRICK?
}

\author{
JEFFREY L. HARRISON*
}

\begin{abstract}
Nineteen seventy-seven was a paradigm-shifting year in antitrust law. Decisions by the Supreme Court greatly limited the type of parties who could successfully bring antitrust actions and what types of activities would violate the antitrust laws. First, in January of that year, the Court, in Brunswick v. Pueblo Bowl-O-Mat, ruled that to mount a case the plaintiff had to have suffered an antitrust injury. In other words, even if the antitrust laws were violated, the party raising the issue had to have suffered the type of harm the laws were designed to avoid. Then in a fourteen day span the Court decided Continental T. V., Inc. v. GTE Sylvania and Illinois Brick Co. v. Illinois. In Sylvania, the Court held that vertical restraints on distribution were to be assessed under the rule of reason as opposed to the per se standard. In so doing the Court adopted reasoning that would carry over to vertical restraints on prices and applied in the context of some horizontal restraint cases. In Illinois Brick, in a six to three decision, it held that indirect purchases could not recover from price fixing firms even if the higher prices were passed onto those purchasers by those purchasing directly from the price fixers. Of these opinions, Illinois Brick has little, if any, continuing justification. This has been true for some time but now that matter is more critical in the aftermath of the Supreme Court decision in Apple Inc. v. Pepper, which exposed after forty years, the indeterminacy of Illinois Brick.
\end{abstract}

*Huber C. Hurst Eminent Scholar, University of Florida College of Law. 
696 WILLIAM \& MARY BUSINESS LAW REVIEW [Vol. 11:695

\section{TABLE OF CONTENTS}

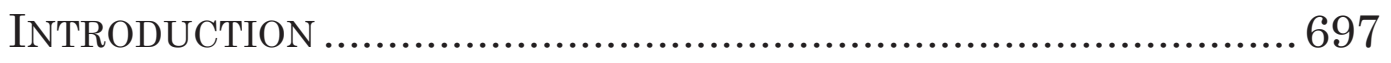

I. The Development of the Direct Purchaser Element of

ANTITRUST STANDING ....................................................... 700

A. Hanover Shoe and Illinois Brick.................................... 700

B. Associated General Contractors ..................................... 705

C. Kansas v. UtiliCorp United, Inc. ................................... 708

II. The Problems With ILlinoIS BRICK IN The Post-SylVANIA

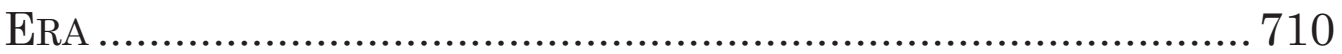

A. The Not-So-Simple Application of Illinois Brick and the Implications of Apple Inc. v. Pepper ................................. 710

1. Pre-Apple Inc. Cases .................................................. 710

2. Apple Inc. v. Pepper................................................... 713

B. Liability Under the Rule of Reason ................................. 717

C. Procedural and Evidentiary Changes Since Illinois

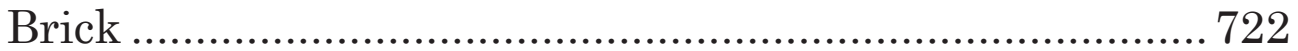

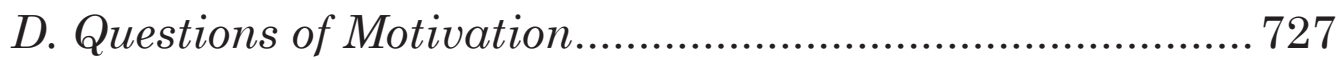

CONCLUSIONS AND RECOMMENDATIONS ................................... 730 


\section{INTRODUCTION}

Nineteen seventy-seven was a paradigm-shifting year in antitrust law. Decisions by the Supreme Court greatly limited the type of parties who could successfully bring antitrust actions and what types of activities would violate the antitrust laws. First, in January of that year, the Court, in Brunswick v. Pueblo Bowl-OMat, ${ }^{1}$ ruled that to mount a case the plaintiff had to have suffered an antitrust injury. In other words, even if the antitrust laws were violated, the party raising the issue had to have suffered the type of harm the laws were designed to avoid. ${ }^{2}$ Then in a fourteen day span, the Court decided Continental T. V., Inc. v. GTE Sylvania ${ }^{3}$ and Illinois Brick Co. v. Illinois. ${ }^{4}$ In Sylvania, the Court held that vertical restraints on distribution were to be assessed under the rule of reason as opposed to the per se standard. ${ }^{5}$ In so doing, the Court adopted reasoning that would carry over to vertical restraints on prices ${ }^{6}$ and applied in the context of some horizontal restraint cases. ${ }^{7}$ In Illinois Brick, in a six to three decision, it held that indirect purchasers could not recover from price fixing firms even if the higher prices were passed onto those purchasers by those purchasing directly from the price fixers. ${ }^{8}$

Of these opinions, Illinois Brick has little, if any, continuing justification. More precisely, it has become irrelevant in the process decreasing error rates in antitrust. ${ }^{9}$ This has been true for some time, but now that matter is more critical in the aftermath of the

${ }^{1}$ Brunswick Corp. v. Pueblo Bowl-O-Mat Inc., 429 U.S. 477, 489 (1977).

${ }^{2}$ Id.

${ }^{3}$ Cont'l T. V., Inc. v. GTE Sylvania Inc., 433 U.S. 36, 36 (1977).

${ }^{4}$ Ill. Brick Co. v. Illinois, 431 U.S. 720, 720 (1977).

${ }^{5}$ See Cont'l T. V., Inc., 433 U.S. at 57-59.

6 See Leegin Creative Leather Prods., Inc. v. PSKS, Inc., 551 U.S. 877, 878, 882 (2007).

7 See, e.g., Polk Bros. v. Forest City Enters., 776 F.2d 185, 189-90 (7th Cir. 1985); Gerlinger v. Amazon.com, Inc., 311 F. Supp. 2d 838, 849 (N.D. Cal. 2004); Rozema v. Marshfield Clinic, 977 F. Supp. 1362, 1378-79 (W.D. Wis. 1997).

8 See Ill. Brick, 431 U.S. at 720.

9 Errors can come in two forms. False positives mean condemning an activity that is pro-competitive or harmless. False negatives mean no response to activities that are actually harmful. Barry Barnett, Fear of False Positives Distorts Antitrust, The Contingency (Aug. 17, 2015), https://www.thecontingency.com/2015/08 /fear-of-false-positives-distorts-antitrust/ [https://perma.cc/5Y6P-M9AR]. 
Supreme Court decision in Apple Inc. v. Pepper ${ }^{10}$ which exposed, after forty years, the indeterminacy of Illinois Brick. The two policies of Illinois Brick were to balance over and under deterrence of the antitrust laws"1 and to avoid "massive evidence and complicated theories" in antitrust litigation. ${ }^{12}$ Antitrust law has changed dramatically in the forty years since Illinois Brick making these policies achievable without the costs Illinois Brick imposes on downstream purchasers. ${ }^{13}$ Thus, like many things-cars, old computers, dated editions of casebooks-Illinois Brick should be retired by being overturned or modified.

The reasons are best understood after a closer examination of Illinois Brick and where it fits in 2020 antitrust jurisprudence but a brief listing of the reasons here is useful. First, as Apple Inc. indicates, new marketing techniques have blurred the distinction between direct and indirect purchasers. ${ }^{14}$ Indeed, today's marketing arrangements were likely unforeseeable by the Court in 1977.

10139 S. Ct. 1514, 1522 (2019). Illinois Brick has received substantial attention in the antitrust literature. See, e.g., Joseph P. Bauer, The Stealth Assault on Antitrust Enforcement: Raising the Barriers for Antitrust Injury and Standing, 62 U. PitT. L. REV. 437, 443 (2001); Roger D. Blair \& Jeffrey L. Harrison, Reexamining the Role of Illinois Brick in Modern Antitrust Standing Analysis, 68 GEO. WASH. L. REV. 1, 1 (1999); Edward D. Cavanagh, Illinois Brick: A Look Back and a Look Ahead, 17 Loy. Consumer L. REv. 1, 1 (2004); Andrew L. Gavil, Thinking Outside the Illinois Brick Box: A Proposal for Reform, 76 ANTITRUST L.J. 167, 16768 (2009); Andrew S. Gehring, The Power of the Purchaser: The Effect of Indirect Purchaser Damages Suits on Deterring Antitrust Violations, 5 N.Y.U. J.L. \& LIBERTY 208, 208 (2010); Barak Richman \& Christopher R. Murray, Rebuilding Illinois Brick: A Functionalist Approach to the Indirect Purchaser Rule, 81 S. CAL. L. REV. 69, 69 (2007); Maarten P. Schinkel, Jan Tuinstra \& Jakob Rüggeberg, Illinois Walls: How Barring Indirect Purchaser Suits Facilitates Collusion, 30 RAND J. ECON. 683, 683 (2008).

11 As will be discussed below, the Court also sought to balance the risk of multiple liability against encouraging parties to act as private attorney generals. Ill. Brick, 431 U.S. at 746.

12 Apple Inc., 139 S. Ct. at 1526. This rationale has always had a tail-waggingthe-dog character. Antitrust cases are complicated by nature but the Court's view seems to be that it is better to risk a false negative than to deal with a complicated process that only relates to the remedy. See id.

13 See id. at 1525.

${ }^{14}$ In Apple Inc., Apple sold iPhone applications that were designed by others. Apple allowed the developers to set the price of the applications and withheld 30 percent of the price charged for itself. Thus, while it was a direct seller, it did not control the price except for requiring all prices to end in $\$ 0.99$. Id. at 1519 . 
More surprising, Apple Inc. reveals that after forty years of application the Court is split on what Illinois Brick stands for. ${ }^{15}$ To the five Justice majority, Illinois Brick provides a bright-line test. ${ }^{16}$ To the four Justice minority it is but an application of a proximate cause analysis. ${ }^{17}$ Second, unlike 1977, now very few practices are per se illegal and rule of reason cases very rarely make it to a stage at which apportioning damages would be necessary. ${ }^{18}$ This also means that to the extent Illinois Brick was based on the fear of multiple liability and over-deterrence, ${ }^{19}$ that risk is now remote. Third, relatively new and higher standards for the introduction of expert testimony, ${ }^{20}$ surviving summary judgment, ${ }^{21}$ and class certification ${ }^{22}$ also mean that many of the dangers outlined in Illinois Brick are only theoretical. Fourth, antitrust standing and antitrust injury analysis developed after Illinois Brick address all the policy concerns of that case, but can be viewed as allowing a more nuanced approach to the question of which parties are eligible to bring an antitrust action. ${ }^{23}$ Finally, there are strong arguments that Illinois Brick was decided incorrectly at the time because it was premised on a mistaken view of damages in price fixing cases. ${ }^{24}$

Before considering these factors and others, Part I takes a close look at Illinois Brick and the cases in its aftermath that establish the indirect purchaser rule. An argument is made that Illinois

15 See infra text accompanying notes 146-88.

16 Apple Inc., 139 S. Ct. at 1524.

17 See infra text at accompanying notes 183-90.

18 For an empirical study, see Michael Carrier, The Rule of Reason: An Empirical Update for the 21st Century, 16 GEO. MASON L. REV. 827 (2009) [hereinafter Carrier, The Rule of Reason]; Michael Carrier, The Real Rule of Reason: Bridging the Disconnect, 1999 B.Y.U. L. REV. 1265 (1999) [hereinafter Carrier, Bridging the Disconnect].

${ }_{19}$ Over-deterrence creates the risk of false positive-results that condemn practices that are harmless or pro-competitive. U.S. DEP'T OF JUSTICE, Competition and Monopoly: Single-Firm Conduct Under Section 2 of the Sherman Act at 13-14 (2008), https://www.justice.gov/atr/competition-and-monopoly-single -firm-conduct-under-section-2-sherman-act [https://perma.cc/CHK6-NZ89].

20 See infra text accompanying notes 269-77.

21 See infra text accompanying notes 249-66.

22 See infra text accompanying notes 280-83.

23 See Apple Inc. v. Pepper, 139 S. Ct. 1514, 1522 (2019).

24 See Herbert Hovenkamp, Federal Antitrust Policy: The Lost Profits Measure of Damages in PRICE Enhancement Cases 725 (West, 4th ed. 2011); Jeffrey L. Harrison, The Lost Profits Measure of Damages in Price Enhancement Cases, 64 Minn. L. REV. 751, 759-60 (1980). 
Brick was limited or even overturned in the Court's principal standing opinion, Associated General Contractors of California $v$. California State Council of Carpenters ${ }^{25}$ and it was not until the 1990 decision in Kansas v. UtiliCorp Inc. that the indirect purchaser rule became iron clad. ${ }^{26}$

The implication of this analysis is that until 1990, the parameters of Illinois Brick were vague. Now, after Apple Inc., the status of Illinois Brick's status is uncertain. In fact, both the majority and dissent in Apple Inc. make arguments that seem to undermine the holding in Illinois Brick. ${ }^{27}$ Part II is the heart of the analysis. Each of the factors that support the notion that Illinois Brick is no more than an antitrust nuisance are discussed. The point made is that the antitrust world has shifted in the forty years since Illinois Brick. Apple Inc. is the latest shift to make Illinois Brick obsolete. In Conclusions and Recommendations, three proposals are offered. One is that Illinois Brick be revisited and overturned and replaced with a reasonably foreseeable standard. Another is that indirect purchasers be permitted to collect from price fixing firms when it is determined that direct purchasers seem unlikely to take action. A final one is that whether plaintiffs are direct or indirect purchasers simply be one factor to be weighed in the analysis.

\section{The Development of the DiRect Purchaser Element of ANTITRUst STANDing}

\section{A. Hanover Shoe and Illinois Brick}

Illinois Brick is actually the second of two cases that raised complementary issues. The first, Hanover Shoe, Inc. v. United Shoe Machinery Corp., was decided nine years earlier. ${ }^{28}$ There a defendant was found to have violated section 2 of the Sherman Act by, among other things, only renting as opposed to selling shoe-making machinery to shoe manufacturers. ${ }^{29}$ The damages were calculated as the difference between the amounts paid to rent the machinery

25459 U.S. 519, 544-46 (1983). For a discussion of this possibility, see supra text accompanying notes 10-24.

${ }^{26}$ See Blair \& Harrison, supra note 10, at 14, 16.

27 See infra text accompanying notes 174-89.

${ }^{28}$ Hanover Shoe, Inc. v. United Shoe Mach. Corp., 392 U.S. 481, 481 (1968).

${ }^{29}$ Id. at 483. 
and the cost to buy the machinery had it been made available for sale. ${ }^{30}$ The Court referred to this as an overcharge. ${ }^{31}$ Defendant, United Shoe, argued that the damages awarded to the plaintiffsshoe manufacturers - should be reduced to the extent those plaintiffs were able to pass on the damages to its own customers. ${ }^{32}$ The Court rejected the "pass[-]on defense," noting that it would be difficult and perhaps only theoretically possible, ${ }^{33}$ to isolate the extent to which the overcharge had been passed-on. In addition, the Court was fearful that treble damage actions would lose much of their effectiveness because dividing up the overcharge among the layers in the chain of distribution would lower the incentives for direct purchasers to bring an action. ${ }^{34}$ In many respects, Hanover Shoe can be seen as promoting the private the enforcement of antitrust law.

After a great deal of scholarly commentary ${ }^{35}$ Illinois Brick, the corollary to Hanover Shoe, was decided in 1977. The Court was composed of only four members who had served on the Hanover Shoe Court and, as evidenced by Sylvania, the Court's approach to antitrust had undergone a change. ${ }^{36}$ Here the issue was whether

30 Id. at $483-84$.

$31 \mathrm{Id}$. at 490 .

$32 \mathrm{Id}$. at 481.

${ }^{33} \mathrm{Id}$. at 493 .

${ }^{34} \mathrm{Id}$. at 494.

35 See, e.g., John Cirace, Price Fixing, Privity, and the Pass-On Problem in Antitrust Treble-Damage Suits: A Suggested Solution, 19 WM. \& MARY L. REV. 171, 171 (1977); Robert C. Harris \& Lawrence A. Sullivan, Passing on the Monopoly Overcharge: A Comprehensive Policy Analysis, 128 U. PA. L. REV. 269, 27071 (1979); Robert Landes \& Richard Posner, Should Indirect Purchasers Have Standing to Sue Under the Antitrust Laws? An Economic Analysis of the Rule of Illinois Brick, 46 U. CHI. L. REV. 602, 602 (1979); Robert Landes \& Richard Posner, The Economics of Passing On: A Reply to Harris and Sullivan, 128 U. PA. L. REV. 1274, 1274 (1980); Bartlett McGuire, The Passing-On Defense and the Right of Remote Purchasers to Recover Treble Damages under Hanover Shoe, 33 U. PiTT. L. REV. 177, 177 (1971); Earl E. Pollock, Automatic Treble Damages and the Passing-On Defense: The Hanover Shoe Decision, 13 AnTITRUst Bull. 1183, 1183 (1968); Elmer Schaefer, Passing-on Theory in Antitrust Treble Damage Actions: An Economic and Legal Analysis, 16 WM. \& MARY L. REV. 883, 884 (1975); Comment, Standing to Sue in Antitrust Cases: The Offensive Use of Passing-On, 123 U. PA. L. REV. 976, 979 (1975); see also Note, The Defense of "Passing On" in Treble Damages Suits Under the Antitrust Laws, 70 YALE L.J. 469, 472 (1961).

36 See E. Thomas Sullivan \& JeFFrey L. Harrison, Understanding ANTITRUST AND ITS ECONOMIC IMPLICATIONS 223-27 (7th ed. 2019); supra text accompanying note 3 . 
overcharges passed-on to indirect purchasers could be recovered by those indirect purchasers. ${ }^{37}$ This is the offensive use of the pass-on rationale. ${ }^{38}$ The Court had three choices. ${ }^{39}$ It could have overturned Hanover Shoe and declared that both offensive and defensive use of the pass-on theory was permitted. ${ }^{40}$ It could have left Hanover Shoe undisturbed and held that offensive use of the pass-on theory was permissible while defensive use was not. ${ }^{41} \mathrm{Fi}$ nally, it could have left Hanover Shoe intact and ruled that offensive use of the theory was not permitted. ${ }^{42}$ In a six-three decision it chose this last possibility. ${ }^{43}$

The Court's analysis involved two steps. ${ }^{44}$ The first step was deciding that plaintiffs and defendants were to be treated alike as far as relying on the pass-on theory. ${ }^{45}$ It rejected the arguments of the dissenters that parallel treatment was unnecessary. ${ }^{46}$ Allowing offensive but not defensive use of the theory would, the Court reasoned, result in a "serious risk of multiple liability." 47 In addition, allowing offensive but not defensive use would give rise to the same tracing complexities addressed in Hanover Shoe, ${ }^{48}$ which stood for the idea that the antitrust law would be more effectively enforced by concentrating the incentive to bring an action in the hands of direct purchasers. ${ }^{49}$

Having decided that plaintiffs and defendants should receive similar treatment, the Court rejected the use of pass-on analysis for both parties. ${ }^{50}$ In dismissing this option, the Court relied to some extent on the lack of legislative action in response to its Hanover Shoe decision. ${ }^{51}$ Mainly, though, the Court was concerned with the complex and massive process of tracing damages

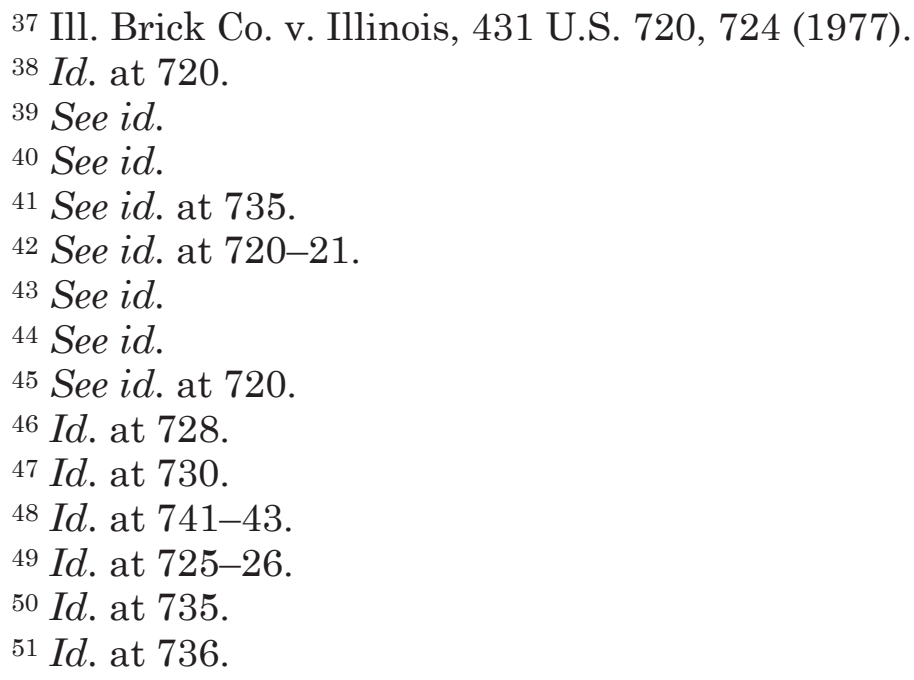


from manufacturer to distributor and so on. ${ }^{52}$ Ultimately, the Court saw itself as choosing between antitrust damages designed to compensate plaintiffs or providing a deterrence to anticompetitive practices. ${ }^{53}$ It reasoned that the compensation goal would dilute the incentives for purchasers at any level to take on the task of acting as a private attorney general. ${ }^{54}$

The Court did leave open the possibility of two exceptions in which indirect purchasers might recover. The first involves preexisting cost-plus contracts. ${ }^{55}$ If an indirect purchaser has a costplus contract with its supplier, then any price increase by that supplier will be passed onto the indirect purchaser. ${ }^{56}$ The second exception occurs when the direct seller is owned or controlled by the indirect seller. ${ }^{57}$

Together, Hanover Shoe and Illinois Brick advance the policies of avoiding complications on the assessments of damages while concentrating incentives for private enforcement of the antitrust laws in direct purchasers. A number of factors are noteworthy. First, the opinion in Illinois Brick is rather cleverly constructed. The Court viewed itself as having to choose between compensation goals and deterrence goals. Yet this was a quandary of the Court's making. It could have achieved both goals by leaving Hanover Shoe intact and allowing offensive use of pass-on theory. It was only left to choose because, in the initial part of the opinion, it rejected the dissenters' arguments that this should be the outcome. Second, Illinois Brick, at some level, can be read to be very pro enforcement. As noted, the Court writes in terms of providing the greatest incentive to direct purchasers. ${ }^{58}$ In actuality, the opinion has become a tool for avoiding liability. ${ }^{59}$ Third, the Court conceded that some direct purchasers would be reluctant to bring actions against suppliers for fear of damaging their relationships. ${ }^{60}$ Still, without offering any compelling reasoning, the Court claimed

\footnotetext{
$52 I d$. at 744 .

${ }^{53} \mathrm{Id}$. at $745-46$.

${ }^{54} \mathrm{Id}$. at 746 .

$55 \mathrm{Id}$. at 736.

${ }^{56} I d$. at 736 n. 16.

$57 \mathrm{Id}$.

$58 \mathrm{Id}$. at 735 .

59 See Blair \& Harrison, supra note 10, at 1.

60 Ill. Brick, 431 U.S. at 746.
} 
that the "private attorney general" theme of the antitrust laws was better served by allowing only direct purchasers to sue. ${ }^{61}$

Fourth, the rationale for the two cases together is somewhat garbled. In Illinois Brick, in particular, the Court cautioned against the risk of multiple liability, which suggests a possibility of over-deterrence and false positives. ${ }^{62}$ On the other hand, it also suggests that allowing offensive use of the pass through theory would dilute private enforcement efforts and, by implication, create a risk of false negatives. ${ }^{63}$ By implication the Court seems to believe there is some correct level of deterrence, but it did not articulate a standard for the balancing process in which it engaged.

In actuality, whatever notion that there is some optimal level of antitrust enforcement behind the Court's analysis was completely undermined a few years later in California $v$. ARC America Corp. ${ }^{64}$ in which the Court upheld the rights of states to enact legislation allowing for indirect purchaser action. In effect, the risk of multiple liability became a function of geography as opposed to any knowable antitrust policy. ${ }^{65}$ In short, whatever role Hanover Shoe and Illinois Brick were thought to play in balancing false positives and false negatives has been rendered moot.

Finally, both decisions are premised on the idea that damages in some cases are measured by the extent to which prices are above the prices that would exist in the absence of a violation. ${ }^{66}$ Furthermore, the pass-on theory means dividing up this gross overcharge among those in the chain of distribution. ${ }^{67}$ This is unnecessary if damages are measured by the actual losses to firms which would be manifested as lost profits. In fact, lost profits seem more in line

$61 \mathrm{Id}$.

${ }^{62}$ False positives are instances of labeling as anticompetitive practices that are actually pro-competitive or, at least, harmless. Erik Hovenkamp \& Herbert Hovenkamp, Tying Arrangements and Antitrust Harm, 52 ARIZ. L. REV. 925, 963 (2010).

63 "False negative" refers to instances in which practices that are anticompetitive are not labeled as such. Lee Goldman, Trouble for the Private Enforcement of the Sherman Act: Twombly, Pleading Standards, and the Oligopoly Problem, 2008 B.Y.U. L. REV. 1057, 1069 (2008).

64490 U.S. 93 (1989); see Blair \& Harrison, supra note 10, at 11-13.

65 It also should have ended discussions about optimal level of antitrust enforcement and sanctions since both federal and state antitrust regimes can exist and have different substantive as well as remedial rules. Cirace, supra note 35, at 174.

66 Ill. Brick, 431 U.S. at 725 n.3.

$67 \mathrm{Id}$. at 726. 
with the statutory requirement that the injury be "in ... business or property."68 In fact, it is possible for an overcharged firm to suffer only minor injury. Oddly, the Hanover Shoe Court actually notes the availability of lost profits as a measure of damages in some cases ${ }^{69}$ but opts for overcharge in reliance on a case in which the overcharge was to a municipality, which obviously could not have suffered a decrease in profit. ${ }^{70}$

Still, Illinois Brick persists. Whether it and Hanover Shoe have played any meaningful role in balancing over and under deterrence is doubtful. ${ }^{71}$ Similarly, the effort to simplify damages calculations has a tail-wagging-the-dog character in that antitrust cases tend to be complicated and damages calculations are often difficult. Nevertheless, courts have not otherwise eliminated entire classes of plaintiffs based on these difficulties. ${ }^{72}$ If all other variables had remained the same as they were in 1977 perhaps Illinois Brick, in particular, was a sensible reaction. ${ }^{73}$ The problem, as the following points out, is that very little in antitrust remains as it was in $1977 .{ }^{74}$ In fact, subsequent events, as discussed below, have made Illinois Brick not much more than an antitrust nuisance. Perhaps most importantly, and as Apple Inc. v. Pepper demonstrates, although Hanover Shoe and Illinois Brick described the consequences of being a direct or an indirect purchaser, neither case established a bright-line test for determining when one is a direct or an indirect purchaser. ${ }^{75}$

\section{B. Associated General Contractors}

Although Hanover Shoe and Illinois Brick seemed straight forward, the Court's 1983 decision in Associated General Contractors

6815 U.S.C $\S 15(a)(2019)$.

69 Hanover Shoe, Inc. v. United Shoe Mach. Corp., 392 U.S. 481, 503 (1968).

70 Id. at 489-90.

${ }^{71} \mathrm{It}$ is worth noting that any coherent policy with respect to optimal levels of antitrust enforcement advanced by Illinois Brick was ended with the passage of indirect purchaser statutes by states, which allow offensive use of the pass-on theory. Thus, the level of exposure of a defendant may depend more on geography than actual harm caused. The statutes were upheld by the Supreme Court in California v. ARC America Corp., 490 U.S. 93, 105-06 (1989).

72 Blair \& Harrison, supra note 10, at 2.

${ }^{73} \mathrm{Id}$. at 25 .

${ }^{74} \mathrm{Id}$.

75 See infra text accompanying notes 146-85. 
of California v. California State Council of Carpenters ${ }^{76}$ introduced an element of vagueness. That case presented the Court with an opportunity to clarify which parties were eligible to bring private antitrust actions by weaving together the interests of deterrence, avoidance of multiple liability, and avoidance of undue complication. ${ }^{77}$ It declined this opportunity and issued an opinion that stands better than most cases for the adage that bad facts make for bad law.

The complaint, simply put, was that various building contractors, who were members of a multi-employer bargaining association, had put pressure on other members and nonmembers to enter into contracts with nonunion firms. ${ }^{78}$ Plaintiffs were unions that claimed to be injured by virtue of what amounted to a group boycott. ${ }^{79}$

In what has become the Court's most important antitrust standing opinion, it held that the unions did not qualify under section 4 of the Clayton Act as "any person" that has been injured in their "business or property." 80 It was not that the union was not a person; it was just not the right person. ${ }^{81}$ The Court interpreted section 4, despite the "any person" language, as permitting only certain parties to have standing. ${ }^{82}$ The Court started by noting that the process of determining which parties were eligible to bring antitrust actions was comparable to common law courts defining proximate cause. ${ }^{83}$ It seems to suggest in this regard that the process involves weighing various factors. Thus, "the infinite variety of claims that may arise make it virtually impossible to announce a black-letter rule that will dictate the result in every case." 84

The Court then goes on to identify the factors to be considered. 85 First, the party must have suffered the type of injury the antitrust laws were designed to avoid. 86 This was, of course, consistent with the Court's decision in Brunswick Corp. v. Pueblo

76 See Associated Gen. Contractors of Cal. v. Cal. State Council of Carpenters, 459 U.S. 519, 544-46 (1983).

${ }_{77} \mathrm{Id}$. at $519-20$.

78 Id. at $522-23$.

${ }^{79} \mathrm{Id}$. at $521-24$.

${ }^{80} \mathrm{Id}$. at 546 .

${ }^{81} \mathrm{Id}$. at 542 .

${ }^{82} \mathrm{Id}$. at 529,535 .

$83 \mathrm{Id}$. at 535

${ }^{84} \mathrm{Id}$. at 536.

$85 \mathrm{Id}$. at 537.

86 Id. at 538. 
Bowl-O-Mat. 87 Antitrust injury is a necessary condition in order to have antitrust standing. ${ }^{88}$ The Court goes on to state "[a]n additional factor is the directness or indirectness of the asserted injury." 89 This, of course, folds Illinois Brick factors into standing analysis. ${ }^{90}$ It is not clear, though, that the Court intended to say, as it seemed to with respect to antitrust injury, that only direct purchasers have standing. Instead, the Court restates the policies underlying Illinois Brick: "[t]he existence of an identifiable class of persons whose self-interest would normally motivate them to vindicate the public interest in antitrust enforcement diminishes the justification for allowing a more remote party ... to perform the office of a private attorney general." 91 The language of the Court does not sound as though one must be a direct purchaser to have standing, although there is definitely a reference for that. ${ }^{92}$ Finally, echoing Hanover Shoe and Illinois Brick, the Court indicated that standing decisions should advance the policies of avoiding duplicative recoveries and overly complicated antitrust trials especially with respect to the issue of damages. ${ }^{93}$ Here again, though, the Court seemed to hedge noting that there was a "strong interest ... in keeping the scope of complex antitrust trials within judicially manageable limits." 94 For reasons that are not clear, the Court envisioned a common fund that would have to be allocated among plaintiffs as opposed to permitting each plaintiff to demonstrate its actual damages..$^{95}$

The question arguably left open by Associated General Contractors was whether the Court had retreated somewhat from what could be called a per se requirement that all plaintiffs must have suffered both antitrust injury and to have suffered it directly. ${ }^{96}$ Further support from this position can be found in the Court's concluding comments:

Other relevant factors - the nature of the Union's injury, the tenuous and speculative character of the relationship between

87428 U.S. 477, 487-88 (1977).

${ }^{88}$ Associated Gen. Contractors of Cal., 459 U.S. at 538.

$89 \mathrm{Id}$. at 540.

$90 \mathrm{Id}$. at $534-35$.

91 Id. at 542 (emphasis added).

$92 \mathrm{Id}$. at 542.

${ }^{93}$ Id. at 543-44.

$94 \mathrm{Id}$. at 543.

$95 \mathrm{Id}$. at 544.

96 See generally id. 
the alleged antitrust violation and the Union's alleged injury, the potential for duplicative recovery or complex apportionment of damages, and the existence of more direct victims of the alleged conspiracy-weigh heavily against judicial enforcement of the Union's antitrust claim. ${ }^{97}$

It is possible, even likely, that Associated General Contractors stands for the proposition that the directness of the antitrust injury is but one factor to we weighed in determining antitrust standing. If so, Associated General Contractors could legitimately be viewed as implicitly limiting Illinois Brick. Certainly, this is not the conventional interpretation and antitrust injury and direct injury have both become necessary for antitrust standing. ${ }^{98}$ It is not necessary, however, to read Associated General Contractors as firmly establishing this outcome. In fact, read closely, it appears that some indirect purchasers would qualify. For example, surely an indirect purchaser who pays a higher price because it buys from a seller who has paid a higher price due to price fixing has suffered the type of injury the antitrust laws were designed to prevent. In addition, the indirect purchaser may be the most likely to bring an action especially if the direct purchaser desires to remain in good standing with its price fixing supplier. ${ }^{99}$ The risk of multiple liability and complications in determining damages only comes into play if the plaintiff is permitted to recover some amount more than actual harm or if a court clings to the mistaken notion that all antitrust damages are manifested as an overcharge. ${ }^{100}$

C. Kansas v. UtiliCorp United, Inc.

Whatever door was left open by Associated General Contractors to allow courts to treat directness of harm as a factor in determining standing was closed in 1990 by the Court's 5-4 decision in Kansas v. UtiliCorp United, Inc. ${ }^{101}$ The very strong position adopted by the smallest possible majority of the Court concerned the standing of ratepayers to whom the cost of natural gas was passed on to by a regulated utility. ${ }^{102}$ The Court correctly viewed

${ }^{97} \mathrm{Id}$. at 545-46 (emphasis added).

98 See generally id.

99 See infra text accompanying notes 295-307.

$100 \mathrm{Id}$.

101 See generally Kansas v. UtiliCorp United, Inc., 497 U.S. 199 (1990).

102 See id. at 204. 
the ratepayers as indirect purchasers and, thus, the issue was framed as whether there should be an exception to Illinois Brick. ${ }^{103}$ The framing of the question is critical. The Court could have said that after Associated General Contractors, directness of injury was but a factor in determining standing. Instead it returned (if it had ever deviated) to the view that directness is a necessary condition of standing. ${ }^{104}$ The ratepayers argued that the complexities avoided by Illinois Brick did not apply when the full overcharge was automatically passed on to them. ${ }^{105}$

According to the Court there were three problems with this position. ${ }^{106}$ First, the implication of the ratepayers' argument was that the utility itself was not injured.107 The Court reasoned that this was impossible to know. ${ }^{108}$ For example, the market may have been ripe for a price increase that would have benefitted the utility. 109 This opportunity may have been removed when the utility was forced to raise prices due to the cost increase. ${ }^{110}$ Second, there could be delays in the passing on process that caused damage to the utility. ${ }^{111}$ Third, the Court indicated that the nature of rate regulation made it unnecessary it compensate ratepayers ${ }^{112}$ because any recovery by the direct purchaser would likely be passed on to ratepayers, thereby off setting any overcharge. The Court also responded to the argument that a utility, if permitted to pass on the overcharge, would not have the incentive to sue its suppliers. ${ }^{113}$ It noted that historically utilities had brought actions under the antitrust laws. ${ }^{114}$ In addition, it was possible utilities that did not sue suppliers would not be permitted to shift avoidable overcharges to consumers. ${ }^{115}$

Ultimately the Court left little room to expand on the possibility of a more nuanced standing analysis as hinted at in Associated

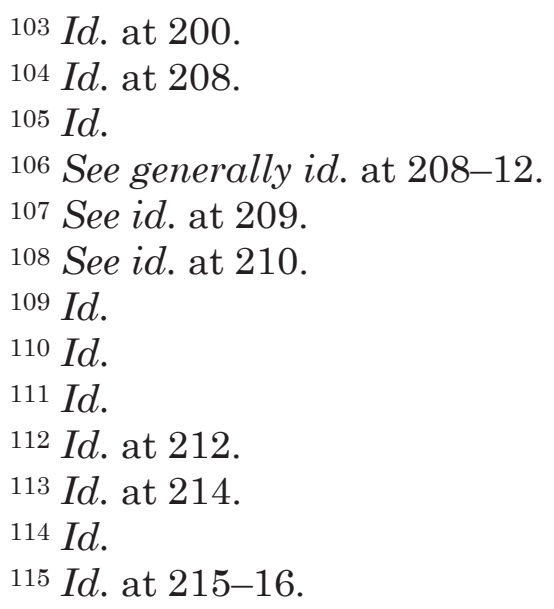


General Contractors. Although it conceded that "the rationales underlying Hanover Shoe and Illinois Brick will not apply with equal force in all cases," 116 it went on to say "[t]he possibility of allowing an exception, even in a rather meritorious case, would undermine the rule." 117

II. The Problems With ILLINOIS BRICK IN THE Post-SyLVANIA ERA

A. The Not-So-Simple Application of Illinois Brick and the Implications of Apple Inc. v. Pepper

Although it seems like Illinois Brick along with UtiliCorp establish a bright-line test, that is not the case. We know what the consequences are when a potential plaintiff is viewed as indirect. What those cases do not tell us, as Apple Inc. v. Pepper demonstrates, is that classifying a party as direct or indirect is not necessarily an easy matter. The indeterminacy has become more important lately as distribution chains, with the advent of the internet, take forms the Court could hardly have imagined 40 years ago. Still the problem is not a new one.

\section{Pre-Apple Inc. Cases}

An early case illustrating this problem is Mid-West Paper Products Co. v. Continental Group. Inc., in which plaintiffs purchased from competitors of the defendant which engaged in price fixing. 118 The allegation was that plaintiffs paid higher prices because their supplier was able to raise prices in light of the higher prices fixed by other sellers. ${ }^{119}$ Plaintiffs were direct purchasers but not from those engaged in price fixing. ${ }^{120}$ Nevertheless, their harm, in terms of paying supercompetitive prices was arguably a direct result of the price fixing. ${ }^{121}$ The Court of Appeals for the Third Circuit applied Illinois Brick in holding that plaintiffs did not have standing. ${ }^{122}$ The court primarily replied on the difficulty

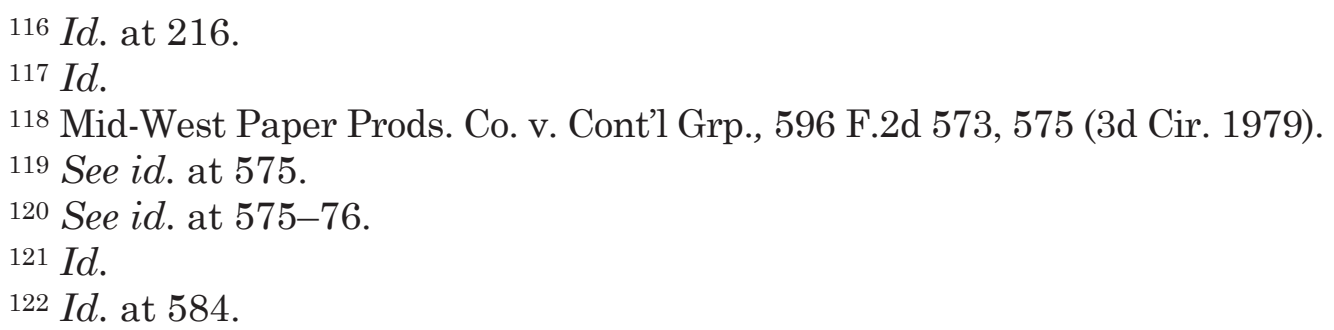


of determining damages when it was unclear how much of the price charged was a result of price fixing and how much was traceable to other variables. ${ }^{123}$ In particular the court noted that even though the plaintiff did not purchase through an intermediary, the actual damages were "indirect" and, therefore, analogous to those suffered by indirect purchasers. ${ }^{124}$

A similar issue arose in In re Lower Lake Erie Iron Ore Antitrust Litigation in which railroads serving the steel industry were alleged to have blocked the entry of lower cost means of transporting iron ore. ${ }^{125}$ The issue was whether steel companies had standing under the theory that they had to pay more to non-conspiring companies. ${ }^{126}$ This time, the same court that had decided Mid-West Paper determined that plaintiffs did have standing because the impact was "directly traceable" 127 to the actions of the defendants. According to the court, current law does not support the conclusion that "indirect purchaser status is the death knell of plaintiff's claim."128 It reasoned that the possibility of duplicate recovery, as cautioned against by Illinois Brick, could be addressed at the proof of damages stage of the proceedings. ${ }^{129}$ The court seemed to redefine "direct purchaser" to mean "a purchaser directly affected."130

The difficulty of applying Illinois Brick is further illustrated by Delaware Valley Surgical Supply Inc. v. Johnson \& Johnson, a more recent decision by the Ninth Circuit Court of Appeals. ${ }^{131}$ The plaintiff, a hospital, in the action purchased supplies indirectly from Johnson \& Johnson. ${ }^{132}$ The price it paid, however, was determined by negotiation between a group-buying organization of which it was a member and Johnson \& Johnson. 133 The actual purchase was made through a distributor but at the price agreed upon by the

${ }^{123} I d$. at 585 .

124 See id. at 585-86.

125 See In re Lower Lake Erie Iron Ore Antitrust Litig., 998 F.3d 1144, 1151

(3d Cir. 1993).

${ }^{126} I d$.

127 Id. at 1167.

${ }^{128}$ Id. at 1168 .

${ }^{129} \mathrm{Id}$. at 1169.

130 See id. at 1168.

131 Delaware Valley Surgical Supply Inc. v. Johnson \& Johnson, 523 F.3d 1116, 1117 (9th Cir. 2008).

132 Id. at 1118.

133 See id. at 1118-19. 
group-buying organization and the plaintiff. ${ }^{134}$ This effectively reduced the middleman to a conduit. Nevertheless, the court, placing form over substance, held that a correct application of Illinois Brick meant the plaintiff lacked standing. 135

Maybe the most confusing and well-known case demonstrating the difficulty of applying Illinois Brick is the 1998 opinion of the Eighth Circuit Court of Appeals in Campos v. Ticketmaster. ${ }^{136}$ Plaintiffs were purchasers of a concert ticket from Ticketmaster. ${ }^{137}$ Ticketmaster had contracts with most concert venues that allowed Ticketmaster to distribute tickets for events held at those venues. ${ }^{138}$ Plaintiffs claimed that Ticketmaster had unlawfully raised the prices of distributing tickets and that they-concertgoers-were direct purchasers of those services. ${ }^{139}$ Here the Eight Circuit Court of Appeals held that the concertgoers were indirect purchasers and, thus, lacked standing under Illinois Brick. ${ }^{140}$ The court viewed the venues as the direct purchasers of distribution services and the concertgoers as indirect purchasers. ${ }^{141}$ In effect, distribution services were first purchased by venues and then the cost passed on to concertgoers. ${ }^{142}$ According to the court, concertgoers were like homeowners who hired a painter to paint their houses. ${ }^{143}$ The painter then purchased the paint and the homeowners were then indirect purchasers of the paint. 144 The form over substance character of this rigid application of Illinois Brick can be understood by noting that the scenario changes if the painter simply tells the homeowner how much paint is needed and the homeowner purchases it. In between is the possibility that the painter itemizes expenses as either cost of paint or cost of labor. In all scenarios,

${ }^{134} I d$.

135 Id. at 1123-24. More recently, the Ninth Circuit sought to distinguish Delaware Surgical Supply in In re Apple iPhone Antitrust Litig., 846 F.3d 313, 323-24 (9th Cir. 2017). That decision lead to Apple Inc. v. Pepper.

136 Campos v. Ticketmaster Corp., 140 F.3d 1166, 1168 (8th Cir. 1998).

137 Id. at 1166.

138 Id. at 1168.

139 Id. at 1171.

${ }_{140} I d$.

${ }^{141} I d$.

142 Id. at 1174.

${ }^{143} I d$. at 1170 .

${ }^{144} I d$. 
the substance is the same yet, since 1977, antitrust enforcement has depended on these non-substantive distinctions. ${ }^{145}$

2. Apple Inc. v. Pepper

The inability of Illinois Brick to deal with increasingly commonplace scenarios is best exemplified by Apple v. Pepper and, in particular, the way it divided the Supreme Court. Notably, after forty years of courts applying Illinois Brick the Supreme Court split on its basic holding. ${ }^{146}$ Plaintiffs were purchasers of smartphone apps who claimed that Apple had monopolized the iPhone app market. ${ }^{147}$ Apple defended by claiming the plaintiffs were indirect purchasers. ${ }^{148}$ Factually, Apple sells apps from its App Store. Some apps are developed by Apple and other are developed by third parties. ${ }^{149}$ When one of the third-party apps is sold, Apple receives a 30 percent commission and the remainder goes to the developer. ${ }^{150}$ Developers are not permitted to sell apps through any other methods of distribution. ${ }^{151}$ Perhaps most important is the fact that Apple does not set the price of the apps. ${ }^{152}$ Those are set by the app suppliers with the only restriction being that the price end in $\$ 0.99 .153$ Before the Supreme Court, Apple's argument was that it sold distribution services to app producers and was, if anything, an indirect seller to consumers, was accepted by the trial court, 154 which found that plaintiffs lacked standing under Illinois Brick. The Ninth Circuit Court of Appeals reversed. 155

Apple was clearly a direct seller to consumers from a formalistic standpoint. ${ }^{156}$ The real issue before the Court was whether Illinois Brick should be applied strictly or extended to protect a

${ }^{145} I d$.

146 The Court was divided five to four. Apple Inc. v. Pepper, 139 S. Ct. 1514, 1515 (2019).

147 Id. at 1518.

148 Id. at 1519.

${ }^{149} I d$.

${ }^{150} I d$.

151 Id.

$152 I d$.

${ }^{153} I d$.

154 In re Apple iPhone Antitrust Litig., No. 11-CV-06714-YGR, 2013 WL 6253147, at *6 (N.D. Cal. Dec. 2, 2013).

155 In re Apple iPhone Antitrust Litig., 846 F.3d 313, 323-24 (9th Cir. 2017).

156 Apple Inc., 139 S. Ct. at 1519. 
direct seller if that seller did not actually set prices but simply received a commission. ${ }^{157}$ Ordinarily one would think that the pricesetting seller has whatever power there is to raise prices above competitive levels and would, thus, be the ultimate target of an antitrust action. That would mean, however, that consumers were one step away from the level at which prices were set and would not be classified as direct purchasers. This is, however, an overly simplistic view of the determinants of price. Apple did not set the price but it did set the 30 percent fee and whatever monopoly overcharge was suffered by the customers was likely in part the result of this 30 percent. ${ }^{158}$ In short, if Illinois Brick were literally applied, then consumers were direct purchasers. ${ }^{159}$ If it were expanded to say that purchasers must buy directly from the price setting parties (in this case the app developers), then consumers were indirect purchasers. ${ }^{160}$

The Court was divided five-four. ${ }^{161}$ The majority stuck to a strict application of Illinois Brick. ${ }^{162}$ Apple was ruled to be a direct seller. ${ }^{163}$ Two aspects of the opinion are especially noteworthy. First the majority noted that any other outcome would mean that a monopoly retailer could avoid liability by allowing a manufacturer to set price and then just retain part of the proceeds from the sale. ${ }^{164}$ Far more important in terms of the continued viability of Illinois Brick, the Court addressed each of the rationales for that opinion and concluded that they did not apply here. ${ }^{165}$ It did this in a manner that could be interpreted as questioning whether any of the rationales for Illinois Brick itself continued to be compelling. ${ }^{166}$ The first rationale, at least according to the majority, was that antitrust law would be more effectively enforced by concentrating the ability to pursue an action in direct purchasers. ${ }^{167}$ According to the majority this was not applicable in this case. 168 Thus:

\footnotetext{
157 Id. at $1522-23$.

158 Id. at 1523.

159 Id. at 1519.

$160 I d$.

${ }^{161} I d$. at 1518.

$162 I d$.

${ }^{163} I d$. at 1525 .

164 Id. at 1522 .

$165 \mathrm{Id}$. at 1525 .

166 Id. at 1524 .

167 Id. at 1522 .

168 Id.
} 
Leaving consumers at the mercy of monopolistic retailers simply because upstream suppliers could also sue the retailers makes little sense and would directly contradict the longstanding goal of effective private enforcement and consumer protection in antitrust cases. 169

Second, Illinois Brick was based on the difficulty of determining damages. ${ }^{170}$ For example in the case at hand, if Apple were found liable the question would be how much lower in price apps would have been if it were found that the 30 percent charge was a product of monopolizing conduct. Here the majority noted that damages calculations are difficult in a great many antitrust cases and that Illinois Brick was not a "get-out-of-jail-free card for monopolistic retailers to play any time that a damages calculation might be complicated."171 Third, the majority considered the rationale of Illinois Brick based on the difficulty of having to apportion a common fund of damages among direct and indirect purchasers. ${ }^{172}$ The majority simply noted in the case at hand there was only one group of potential plaintiffs. ${ }^{173}$

When the dissenting opinion is considered along with the majority opinion, what Apple Inc. illustrates is the unworkability of Illinois Brick. In a very sharply worded opinion written by Justice Gorsuch, the dissent viewed the issue in Apple Inc. as involving "exactly the kind of "pass-on theory' Illinois Brick rejected." 174 Specifically, the minority reasoned, the 30 percent charge was something app suppliers were required to pay-like a cost of production. ${ }^{175}$ Those suppliers then determined the price to charge for the apps. ${ }^{176}$ In other words, whatever Apple may have done in violation of the antitrust laws had its initial impact on app developers who then passed-on that overcharge to consumers. ${ }^{177}$

${ }^{169} \mathrm{Id}$. at 1524.

${ }^{170} I d$.

${ }^{171} \mathrm{Id}$.

${ }^{172} I d$. at $1524-25$.

${ }^{173} I d$. at 1525 . The Court did note that there may be multiple plaintiffs but that was normal in a great many cases. Also, it noted that Apple might be sued for monopolization by buyers and for monopolization by suppliers of apps. In this case, the damage theories would differ. $I d$.

${ }^{174} I d$. at 1528 (Gorsuch, J., dissenting).

$175 I d$.

$176 I d$.

$177 \mathrm{Id}$. 
The dissent went on to argue that all the policies that were advanced by Illinois Brick came into play in the instant case. ${ }^{178}$ For example, a court would have to determine to what extent Apple's practices caused harm to the app developers and then of how much of the overcharge was actually passed onto consumers. ${ }^{179} \mathrm{In}$ fact, there could be separate lawsuits by developers and consumers each wanting a piece of the overcharge pie ${ }^{180}$ and a resulting risk of duplicative recoveries. ${ }^{181}$

More important than these opposing views with respect to the practical effects of ruling one way or another is the clear indication that the Court is fundamentally divided over what Illinois Brick stands for. According to the dissent, the majority:

(re)characterizes Illinois Brick as a rule that anyone who purchases goods directly from an alleged antitrust violator can sue, while anyone who doesn't, can't. Under this revisionist version of Illinois Brick, the dispositive question becomes whether an "intermediary in the distribution chain" stands between the plaintiff and the defendant. And because the plaintiff app purchasers in this case happen to have purchased apps directly from Apple, the Court reasons, they may sue. ${ }^{182}$

The dissent's view was that Illinois Brick did not require a formalistic assessment of who were direct as opposed to indirect purchasers. ${ }^{183}$ Instead the underlying rationale for Illinois Brick was one of proximate cause. ${ }^{184}$ Thus, according to the dissent, "[i]nstead of focusing on the traditional proximate cause question where the overcharge is first (and thus surely felt) the Court's test turns on who happens to be in privity of contract with whom."185

In short, to the majority Illinois Brick provided a bright-line test of who was eligible to bring an antitrust action. ${ }^{186}$ To the dissent, Illinois Brick stood for a proximate cause analysis and, under the

\footnotetext{
178 Id. at $1528-30$.

$179 \mathrm{Id}$. at 1528.

$180 \mathrm{Id}$. at 1529 .

${ }^{181} \mathrm{Id}$.

182 Id.

${ }^{183} I d$. at 1526.

184 Id.

$185 I d$. at 1529.

186 Id. at 1515 .
} 
fact pattern in that case, it just so happened that direct purchasers were not within the scope of proximate causation. ${ }^{187}$

Ironically, both the majority and the dissent seem to undercut Illinois Brick itself. The majority downplays the policies that were supposedly advanced by Illinois Brick arguing that they simply do not apply in Apple Inc. $v$. Pepper. ${ }^{188}$ In fact, it notes that all antitrust cases involve difficulties in determining damages. ${ }^{189}$ As a general matter, it comes very close to opining that the dangers Illinois Brick was designed to avoid were overstated. On the other hand, under the dissent's "proximate cause" analysis one wonders what purpose Illinois Brick serves. Taken to its logical end, the indirect purchaser element of determining antitrust standing should be assessed on a case-by-case basis.

\section{B. Liability Under the Rule of Reason}

As noted at the outset, Illinois Brick reflects a policy of limited liability. ${ }^{190}$ That may have made sense in the context of 1960s and 1970 s antitrust law. In that period a great number of practices were per se unlawful that are now assessed under the rule of reason. ${ }^{191}$ This raised the risk of false positives-finding that pro-competitive or harmless practices were unlawful. ${ }^{192}$ This has changed and there are few per se rules left. ${ }^{193}$ In addition, the per se rules that still exist have been softened. ${ }^{194}$ More importantly, empirical evidence is now available that demonstrates that, under current law, plaintiffs rarely prevail. 195

As indicated in the Introduction, the Sylvania case made the most important change in antitrust by ruling that vertical restraints on distribution would be assessed under the rule of reason. ${ }^{196}$

${ }^{187} I d$. at 1526.

188 Id. at 1524 .

${ }^{189} I d$.

190 See supra text accompanying note 19.

191 See United States v. Arnold, Schwinn \& Co., 388 U.S. 365 (1967). See generally THE LAW OF ANTITRUST: AN INTEGRATED HANDBOOK 253-54 (2d ed. 2006); Sullivan \& HARRISON, supra note 36, at 223-24. A good summary of developments is found in State Oil v. Kahn, 522 U.S. 3 (1997).

192 Carrier, The Rule of Reason, supra note 18, at 828.

${ }^{193} I d$.

194 See infra text accompanying notes 214-29.

195 See infra text accompanying notes 229-47.

196 Cont'l T. V. Inc. v. GTE Sylvania Inc., 433 U.S. 36, 59 (1977). 
More importantly, the Court introduced the notion that restraints on intrabrand competition might be a necessary part of a plan to increase interbrand competition. ${ }^{197}$ It also noted the free rider problems faced by manufacturers who wanted resellers to be more aggressive in sales efforts. 198

Changing the status of restraints on distribution left intact vertical maximum and vertical minimum price fixing. ${ }^{199}$ These too, however, were eventually placed in the rule of reason category. ${ }^{200}$ In State Oil v. Kahn, ${ }^{201}$ the Court overturned Albrecht v. Herald Co., ${ }^{202}$ a 1967 case that held that vertical maximum resale price fixing was per se unlawful. The Albrecht Court reasoned that maximum prices could impede efforts by dealers to promote their products by offering services. ${ }^{203} \mathrm{Kahn}$, however, noted that the per se status of vertical maximum price fixing would encourage vertical integration. ${ }^{204}$ Moreover, it was unlikely that manufacturers would set prices so low that their resellers' efforts would be impeded. ${ }^{205}$

It was not until 2007, in Leegin Creative Leather Products $v$. $P K S$, Inc., ${ }^{206}$ that the nearly 100-year-old per se prohibition on setting minimum resale prices was overturned. Although there was a substantial delay of 30 years since Sylvania, the decision in Leegin was largely a result of that case. ${ }^{207}$ In effect, manufacturers may find it advantageous in interbrand markets to restrict intrabrand competition based on price. ${ }^{208}$ Specifically, manufacturers finding that non-price competition was advantageous were faced with the free rider problem. ${ }^{209}$ Resellers offering more services to customers might find they were undercut by discounters who did not offer comparable services. ${ }^{210}$

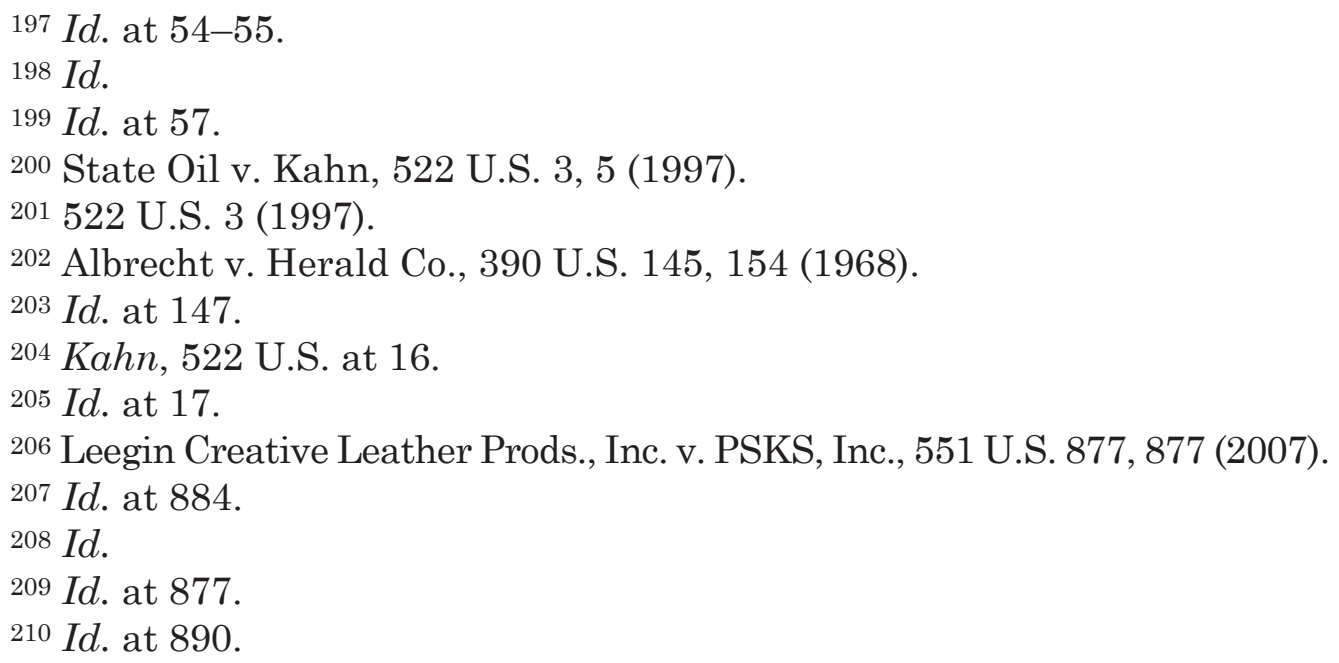


In the case of two other vertical restraints-exclusive dealing 211 and tying ${ }^{212}$ - the shift in approach has been slightly less pronounced but it is nevertheless clear that the burden on plaintiffs is higher than prior to Sylvania. In the case of exclusive dealing it was once felt that the actual impact on competition need not be shown as long as a substantial share of a market was foreclosed to competitors. ${ }^{213}$ Now the approach has shifted to something closer to if not exactly like a rule of reason analysis. ${ }^{214}$ Specifically, courts have recognized the importance of exclusive dealing as a means of promoting interbrand competition. ${ }^{215}$ In effect, resellers who must only sell one brand will make maximum efforts to promote sales of that brand and will be limited in their ability to free ride on the efforts of the manufacturer. ${ }^{216}$

The analysis of tying arrangements has undergone a similar evolution. ${ }^{217}$ Early cases can fairly be said to have found that tying was per se unlawful ${ }^{218}$ as long as two products were involved and the defendant possessed power in the tying product and effected a substantial dollar amount of commerce in the tied product market. Although the Supreme Court has not yet officially taken tying out of the per se category, it has added the requirement that the buyer actually be forced to purchase the tying product. ${ }^{219}$ In addition, the Court and lower courts seem more willing to question whether there are economic reasons regarding the "products" involved as a single product ${ }^{220}$ and to consider pro-competitive justifications. ${ }^{221}$

211 Under an exclusive dealing arrangement, a reseller may only deal in the goods of its supplier. See SULLIVAN \& HARRISON, supra note 36, at 231.

212 See Jefferson Parish v. Hyde, 466 U.S. 2, 12 (1984).

213 Standard Oil Co. v. United States, 337 U.S. 293, 299 (1949).

214 See SUlLIVAN \& HARRISON, supra note 36, at 231.

215 See, e.g., American Motor Inns, Inc. v. Holiday Inns, Inc., 521 F.2d 1230, 1255 (3d Cir. 1975); Joyce Beverages of N.Y. Inc. v. Royal Crown Cola Co., 555 F. Supp. 271, 271 (S.D.N.Y. 1983). See generally Richard M. Steuer, Exclusive Dealing After Jefferson Parish, 54 ANTITRUsT L.J. 1229 (1985).

216 Steuer, supra note 215, at 1235.

217 Jefferson Parish, 466 U.S. at 2.

218 See N. Pac. Ry. Co. v. United States, 356 U.S. 1, 12 (1958).

219 See Jefferson Parish, 466 U.S. at 12.

${ }^{220}$ A good example of this is found in the four Justice concurrence in Jefferson Parish, 466 U.S. at 11-12. See also the analysis in United States v. Microsoft Corp., 253 F.3d 34 (D.C. Cir. 2001).

221 See Ill. Tool Works v. Indep. Ink, 547 U.S. 28, 36 (2006); Microsoft, 253 F.3d at 34. See generally Hovenkamp \& Hovenkamp, supra note 62, at 964. 
The movement toward defendant-favoring standards of analysis has likewise extended to horizontal restraints where per se rules have been softened. ${ }^{222}$ The clearest sign of this shift came in two cases. ${ }^{223}$ In National Society of Professional Engineers $v$. United States, the Supreme Court seemed to relax the per se rule as it applied to price fixing in instances involving professional standards. ${ }^{224}$ More importantly, in Broadcast Music Inc. v. Columbia Broadcasting System, ${ }^{225}$ the Court noted that the per se rule against price fixing was not to be applied literally but depended on whether the practice was designed to "increase economic efficiency and render markets more, rather than less, competitive." 226 In effect, the label "per se price fixing" was not to be applied until a harm/benefit analysis took place. ${ }^{227}$

Similarly, after a period during which group boycotts were felt to be per se unlawful, 228 the Court seemed to revise its thinking. In Northwest Stationers v. Pacific Stationary and Printing Co., ${ }^{229}$ the Court said that the per se label had been reserved for instances in which the boycotting firms possess market power, denied the boycotted firm access to suppliers or customers, and were not consistent with enhancing overall efficiency. ${ }^{230}$ As with Broadcast Music, the announced approach necessitated a measuring of harms and benefits before applying the per se label. ${ }^{231}$

This major shift away from per se rules means that, except in very few instances, cases are now assessed under the rule of reason. ${ }^{232}$ It is not an exaggeration to say that the rule of reason means that defendants prevail in the vast majority of cases. ${ }^{233}$ This means that the multiple liability danger that was at the heart

${ }^{222}$ See Nat'l Soc'y of Prof'l Eng'rs v. United States, 435 U.S. 679, 679 (1978).

${ }^{223}$ See generally Broad. Music Inc. v. Columbia Broad. Sys., 441 U.S. 1 (1979);

Nat'l Soc'y of Prof'l Eng'rs', 435 U.S. at 679.

224 Nat'l Soc'y of Prof'l Eng'rs', 435 U.S. at 679.

225441 U.S. at 1.

${ }^{226} I d$. at 20.

227 See id.

228 See Klor's, Inc. v. Broadway-Hale Stores, Inc., 359 U.S. 207, 212 (1959).

229472 U.S. 284 (1985).

230 Nw. Stationers v. Pac. Stationary \& Printing Co., 472 U.S. 284, 294 (1985).

$231 \mathrm{Id}$.

232 Carrier, The Rule of Reason, supra note 18, at 828.

233 Id. 
of Illinois Brick is no longer a threat (if it ever was). ${ }^{234}$ Two empirical studies by Michael Carrier illustrate just how much the odds are against plaintiffs under the rule of reason. ${ }^{235}$ First, it is useful to recall the progression in a rule of reason case. Initially the plaintiff has the burden of demonstrating that the defendant's action was anticompetitive. ${ }^{236}$ Typically this means defining the market and assessing the action's impact in the market. ${ }^{237}$ The burden then shifts to the defendant to demonstrate that the practice had pro-competitive impact. ${ }^{238}$ At that point, the plaintiff may attempt to show that there are less restrictive methods of achieving the pro-competitive effects. ${ }^{239}$ After that, the actual pro and anticompetitive effects are weighed. ${ }^{240}$

Carrier examined all rule of reason cases in the period from 1977 (the year of Sylvania) to $1999 .{ }^{241}$ There were 495 cases. $^{242}$ Of these, 84 percent did not make it past the first step. ${ }^{243}$ In other words, 84 percent of the time plaintiffs lost even before any balancing of pro- and anticompetitive effects took place. ${ }^{244}$ In fact, the balancing step was only reached in 4 percent of cases with the vast majority having been dismissed in the defendant's favor. ${ }^{245}$ Carrier updated his study in 2009, this time with a sample of 222 rule of reason cases. ${ }^{246}$ The results were even more pronounced. This time, nearly 97 percent of rule of reason cases were dismissed at the first stage of the analysis. ${ }^{247}$ In fact, only five cases made it to the balancing stage. ${ }^{248}$ The salient point is that since there is rarely liability under the rule of reason, the fears of complicated processes

234431 U.S. 720 (1977).

235 Carrier, The Rule of Reason, supra note 18, at 827; Carrier, Bridging the Disconnect, supra note 18, at 1265.

236 Carrier, Bridging the Disconnect, supra note 18, at 1268.

237 Id.

$238 I d$.

239 Id. at 1265.

240 Carrier, The Rule of Reason, supra note 18, at 827.

${ }^{241}$ Carrier, Bridging the Disconnect, supra note 18, at 1265.

242 Id. at 1272.

${ }^{243} I d$. at 1265 .

${ }^{244} \mathrm{Id}$. at 1360.

245 Id. at 1364.

${ }^{246}$ Carrier, The Rule of Reason, supra note 18, at 829.

247 Id.

$248 I d$. 
of apportioning damages and multiple liability as expressed by the Illinois Brick Court simply do not exist. Moreover, a policy, as evidenced by Illinois Brick, of limited exposure of defendants to indirect purchasers for fear of generating false positives is unsupportable.

\section{Procedural and Evidentiary Changes Since Illinois Brick}

The policies underpinning Illinois Brick have also become moot because of changes in the law since 1977 dealing with pleading standards, expert testimony, and class certification. The critical case with respect to the first of these is Bell Atlantic Corp. v. Twombly, ${ }^{249}$ a 2007 Supreme Court decision. That decision raised the bar for antitrust plaintiffs by changing what was necessary to avoid a motion to dismiss under Rule 12(b)(6) of the Federal Rules of Civil Procedure. ${ }^{250}$ Section 1 of the Sherman Act requires that the defendants entered into an actual agreement. ${ }^{251}$ In Twombly, plaintiffs sought to meet the pleading requirements by stating that the defendants had engaged in parallel conduct. ${ }^{252}$ From this, the inference to be drawn was that they had agreed on their anticompetitive actions. ${ }^{253}$ Under prior law, a complaint was not to be dismissed unless "it appear[ed] beyond doubt that the plaintiff [could] prove no set of facts in support of his claim which would entitle him to relief." 254

Although parallel conduct is certainly consistent with the existence of an agreement, as the Twombly Court noted, ${ }^{255}$ it is also consistent with the absence of an agreement. Accordingly, parallel conduct is "just as much in line with a wide swath of rational and competitive business strategy unilaterally prompted by common perceptions of the market." 256 Based on this, it agreed with the trial court that the complaint should be dismissed. ${ }^{257}$ In so doing, it announced a new and higher pleading standard.258 That standard was a requirement of fact that made the existence

\footnotetext{
249550 U.S. 544 (2007).

$250 \mathrm{Id}$. at 570.

$251 \mathrm{Id}$. at 545 .

252 Id. at 544 .

${ }^{253} \mathrm{Id}$. at 548 .

${ }^{254}$ Conley v. Gibson, 355 U.S. 41, 45-46 (1957).

255550 U.S. at 553.

$256 \mathrm{Id}$. at 554 .

257 Id. at 549.

258 Id. at 569.
} 
of a conspiracy "plausible" 259 not merely possible under some sets of circumstances.

There can be little doubt that Twombly was intended to raise the bar for plaintiffs. ${ }^{260}$ It increases the burden at the pleading stage and requires the assertion of facts that may not be known until after discovery. ${ }^{261}$ Just how high the bar has been raised is the subject of disagreement. ${ }^{262}$ Moreover, raising the bar does not necessarily mean increasing the rate of dismissals. ${ }^{263}$ In fact, a comprehensive 2017 study of the impact of Twombly on cases generally indicates that the dismissal rates before and after Twombly are basically the same. ${ }^{264}$ This may reflect the failure of lower courts to interpret Twombly as requiring a change from prior pleading practices. ${ }^{265}$ It also may simply note an adjustment in actual pleadings in order to avoid the implications of Twombly. ${ }^{266}$ Whatever the adjustment, the fact that it must be made at all inures to the benefit of antitrust defendants. ${ }^{267}$

A change with respect to admissible evidence in the postIllinois Brick era has also likely affected the prospects for private antitrust plaintiffs. Recall that the Illinois Brick Court feared being enmeshed in a complicated process of apportioning a fixed overcharge amount among plaintiffs in the chain of distribution and the threat of multiple liability. ${ }^{268}$ Whatever the validity of the Court's rationale in 1977, it is questionable by virtue of its 1993

259 Id. at 545.

$260 I d$.

${ }^{261} I d$.

262 See Keith Bradley, Pleading Standards Should Not Change after Bell Atlantic v. Twombly, 102 Nw. U. L. CoLlOQUY 117, 117 (2007); Goldman, supra note 63, at 1057; Kendall W. Hannon, Much Ado about Twombly: A Study of the Impact of Bell Atlantic Corp. v. Twombly on 12 (b)(6) Motions, 83 Notre Dame L. Rev. 1811, 1814 (2008); Jonathan M. Herman, Jaime Stilson \& Kaleb McNeely, Plausibility in the Eye of the Beholder: Circuits Address How to Read Twombly, 32 AnTitRUst 32, 32 (2017); William H. J. Hubbard, The Effect of Twombly and Iqbal, 14 J. EM. LEG. STUD. 474, 474 (2017); Randal C. Picker, Twombly, Leegin, and the Reshaping of Antitrust, 2007 SUP. CT. REV. 161, 161 (2007).

263 Hubbard, supra note 262, at 474.

${ }^{264} \mathrm{Id}$. at 475 .

${ }^{265}$ Herman et al., supra note 262, at 32.

266 Hubbard, supra note 262, at 505.

267 Bell Atl. Corp. v. Twombly, 550 U.S. 544, 596 (2007).

268 Ill. Brick Co. v. Illinois, 431 U.S. 720, 720 (1977). 
decision in Daubert v. Merrell Dow Pharmaceuticals, Inc. ${ }^{269}$ In that case the Court ratcheted up the requirement for the introduction of expert testimony, a great deal of which is about the subject of damages. ${ }^{270}$ Under the so-called Frye ${ }^{271}$ standard, expert testimony, to be admissible, had to be generally accepted in the relevant scientific community. ${ }^{272}$ Daubert established additional factors for the introduction of expert testimony, including whether the methodology "can be (and has been) tested," 273 whether it has been subjected to "peer review and publication," 274 "the known or potential rate of error," 275 and acceptance in a specifically recognized scientific community. ${ }^{276}$ All of these requirements are in service to Federal Rule of Evidence 702, which allows admissibility when the evidence "will help the trier of fact to understand the evidence or to determine a fact in issue." 277

The implications of Daubert on Illinois Brick may not be immediately obvious. It is important, though, to recall that Illinois Brick excludes parties who are admittedly harmed by those violating the antitrust law because recognition of their right to bring an action would render matters too complicated. ${ }^{278}$ If it is to have any substantive import, the Court must mean that outcomes with respect to harm would be unreliable because of the complexity of determining damages. Obviously, the reasoning has a tail-waggingthe-dog element: because determination of the appropriate remedy is difficult, the plaintiff is denied the opportunity to demonstrate

269509 U.S. 579 (1993). See generally Andrew I. Gavil, Defining Forensic Economics in the Post-Daubert/Kumho Tire Era: Case Studies from Antitrust, 57 Wash. \& LeE L. REV. 831 (2000); Michele Molyneaux, Comment, Quality Control of Economic Expert Testimony: The Fundamental Methods of Proving Antitrust Damages, 35 ARIZ. ST. L.J. 1049 (2003); Molly L. Zohn, Comment, How Antitrust Damages Measure Up With Respect to Daubert Factors, 13 GEO. MASON L. REV. 697 (2005).

270 Daubert, 509 U.S. at 579.

${ }^{271}$ Frye v. United States, 293 F. 1013, 1014 (1923).

272 Id

273 Daubert, 509 U.S. at 593.

${ }^{274} I d$.

275 Id. at 594.

$276 I d$.

277 FED. R. EvID. 702(a).

278 Ill. Brick Co. v. Illinois, 431 U.S. 720, 728 (1977). 
liability. Nevertheless, after Daubert, the problem of complexity and uncertainty can be dealt with at the point of the admissibility of evidence. If a judge determines the submission is not helpful to the trier of fact, it can be excluded. Plaintiffs with difficult to prove damages may choose to forgo bringing an action. On the other hand, with modern econometric methods, the complications of 1977 may be far less troublesome today. ${ }^{279}$

Changes that undermine the need for Illinois Brick can also be traced to modifications in certifying classes in antitrust action. The drift in this respect has been in the direction of requiring those attempting to certify a class to bear the burden of proof on the merits of the underlying theory of liability. ${ }^{280}$ The harm to be avoided, arguably, is that the easy certification of a class may result in settlement of relatively meritless suits. ${ }^{281}$ Although not an antitrust case, the most important decision in this regard is WalMart Stores, Inc. v. Dukes. ${ }^{282}$ The principal issue in Wal-Mart was whether a group wishing to be certified as a class satisfied the commonality requirement under Federal Rules of Civil Procedure 23(a)(2) and predominance under Rule 23(b)(3).283

The case involved accusations of gender discrimination against Wal-Mart. ${ }^{284}$ According to the court, in order to satisfy class certification requirements, it was not enough to simply allege

279 Id.

${ }^{280}$ According to the Supreme Court in Wal-Mart Stores Inc. v. Dukes, this is often the case. 564 U.S. 338, 351-52 (2011).

281 See Halliburton Co. v. Erica P. John Fund, Inc., 573 U.S. 258, 275 (2014);

White v. Goodman, 200 F.3d 1016, 1019 (7th Cir. 2000).

282564 U.S. 338 (2011).

${ }^{283}$ Id. at 349. The Federal Rules of Civil Procedure are as follows:

(a) Prerequisites. One or more members of a class may sue or be sued as representative parties on behalf of all members only if:

1. the class is so numerous that joinder of all members is impracticable;

2. there are questions of law or fact common to the class;

3. the claims or defenses of the representative parties are typical of the claims or defenses of the class; and the representative parties will fairly and adequately protect the interests of the class.

FED. R. Civ. P. 23(a)(2), (b)(3).

${ }^{284}$ Wal-Mart Stores, 564 U.S. at 343. 
that Wal-Mart engaged in discriminatory conduct. ${ }^{285}$ Instead, it was necessary to present "significant proof" that Wal-Mart "operated under a general policy of discrimination." 286 In effect, the merits of the case became intertwined with the issue of class certification.

According to one commentator who has followed class certification requirements in the context of antitrust cases, the 2011 decision in Wal-Mart Stores was "anticlimactic."287 The merging of issues of commonality and predominance for class certification purposes with the merits of the case had already occurred in antitrust. ${ }^{288}$ In the context of this analysis, this represents an additional barrier to plaintiffs and another reason that Illinois Brick's protection of defendants is unwarranted. For example, in In re New Motor Vehicle Canadian Export Antitrust Litigation, ${ }^{289}$ a suit brought by buyers and lessees of automobiles, the Court of Appeals for the First Circuit noted, with respect to class certification, that "[i]ntertwined with the scope of our review on appeal is the question of how far a district court should go in testing legal and factual premises at the certification stage. When such premises are disputed, the court may "probe beneath the pleadings." 290 In reversing the lower court's decision to certify the class, the appellate court required "a more thorough explanation of how the pivotal evidence behind plaintiff's theory can be established. If there is no realistic means of proof, many resources will be wasted setting up a trial the plaintiffs cannot win." 291

Similar in tone is Blades $v$. Monsanto, ${ }^{292}$ in which the proposed class was composed of farmers who purchased corn and soybean seeds at prices that were allegedly the result of price fixing.

285 Id. at 350.

${ }^{286}$ Id. at 353 (quoting Gen. Tel. Co. of Sw. v. Falcon, 457 U.S. 147, 159 n.15 (1982)).

287 Joshua P. Davis \& Eric L. Cramer, A Questionable New Standard for Class Certification in Antitrust Cases, ANTITRUsT 31, 31 (2011); see also Hal J. Singer, Economic Evidence of Common Impact for Class Certification in Antitrust Cases: A Two-Step Analysis, 25 AnTITRUst 34, 34 (2010).

288 Davis \& Cramer, supra note 287, at 31-32.

289522 F.3d 6, 6 (1st Cir. 2008).

290 In re New Motor Vehicles Canadian Exp. Antitrust Litig., 522 F.3d 6, 17

(2008) (quoting Gen. Tel. Co. of Sw. v. Falcon, 457 U.S. 147, 160 (1982)).

291 Id. at 29.

292400 F.3d 562, 567 (8th Cir. 2005). 
Here, the court announced the premise for its analysis: "[t]he preliminary inquiry at the class certification stage may require the court to resolve disputes going to the factual setting of the case, and such disputes may overlap the merits of the case." 293 The Court of Appeals for the Eighth Circuit then went on to affirm the lower court's denial of certification. ${ }^{294}$ Specifically, it rejected the expert testimony for the plaintiffs because it did not consider "whether the markets or the alleged conspiracy at issue here actually operated in such a manner as to justify [the] presumption"295 that impact can be determined on a class-wide basis.

The overall point is that whatever fears may have existed in 1977 about multiple liability and complexity seem far less justified today, if they are even justified at all. New pleading standards have raised the burden of successful litigation to plaintiffs. ${ }^{296}$ After Daubert, complexity may still exist, but a court is free to exclude testimony that is not sound and unlikely to help the trying of fact. ${ }^{297}$ Finally, the danger that liberal class certification will lead to meritless claims by classes of plaintiffs has surely declined after Twombly and the merger of class certification issues with issues of liability.

\section{Questions of Motivation}

A critical element of Illinois Brick is the Court's decision to choose deterrent over-compensation as the primary goal of antitrust damages. The problem is that there is little or no reason to believe that, as an empirical matter, direct purchasers have been more aggressive private enforcers of the antitrust laws than indirect purchasers. First, many direct purchasers may fear offending suppliers on which they depend. Second, it is possible that firms that are able to pass on most or all of an overcharge are simply not motivated to pursue an award that may be perceived as a windfall.

293 Id.

${ }^{294} I d$. at 572.

$295 \mathrm{Id}$. at 570.

296 See Bell Atl. Corp. v. Twombly, 550 U.S. 544, 555-56 (2007).

297 See Daubert v. Merrell Pharms., Inc., 509 U.S. 579, 592-93 (1993). 
On the issue of the aggressiveness of direct purchasers, one excellent example is the case of Campos $v$. Ticketmaster, discussed earlier. ${ }^{298}$ There, it will be recalled, purchasers of tickets through Ticketmaster were classified as indirect purchasers of tickets. ${ }^{299}$ The direct purchasers of Ticketmaster's services supposedly were the venues at which concerts were held. ${ }^{300}$ The problem is those socalled direct purchasers had no motivation to sue Ticketmaster. They were involved in a transaction with Ticketmaster but, as Joseph Bauer has observed, "this was clearly not a situation where Ticketmaster had created a product and then sold it at an elevated price to its 'direct purchaser,' which in turn sold it to the indirect purchaser plaintiffs." 301 In fact, the question becomes on what basis the venues would have recovered. They did not purchase tickets, nor did they pay for ticket distribution services. ${ }^{302}$ There are other instances which create doubt about the Court's belief that purchasers would be the most motivated to bring actions. ${ }^{303}$ According to an American Antitrust Institute Working Paper, "[i]n the Microsoft class action litigation, no significant direct purchaser class was ever certified, leaving the vast majority of direct purchasers uncompensated." 304 In fact, it was estimated that of possibly billions of dollars of damages, only $\$ 10.5$ million were ever recovered. ${ }^{305}$

There are good reasons for direct purchasers to not pursue actions against their suppliers. The most obvious one is that the supplier or suppliers may possess market or monopoly power. If the supplier or suppliers are the primary or only sources of needed inputs, a lawsuit may mean the end of what was a critical relationship. Another theory, forwarded by Barak Richman and Christopher Murray, is that price fixing suppliers may actually

298140 F.3d 1166 (8th Cir. 1998). See supra text accompanying notes 136-45.

299 Id. at 1171.

$300 I d$.

301 Bauer, supra note 10, at 447.

302 Id.

${ }^{303}$ Gavil, supra note 10, at 191-92.

304 Comments of the American Antitrust Institute Working Group on Remedies, AM. ANTITRUST INST. 19 (June 17, 2005), https://www.antitrustinstitute.org/wp -content/uploads/2018/08/423.pdf [https://perma.cc/CV24-H6LD].

305 Id. at 19 n.41. 
share the benefits of their activities with direct purchasers. ${ }^{306}$ The authors base their theory on the idea that "an upstream cartel can prevent private litigation as long as it assures that its direct purchasers downstream benefit more from the existence of the cartel than they can claim antitrust damages for."307

There are no doubt cases in which direct purchasers do not fear retaliation by the price fixing cartel and are not actually made better off by virtue of sharing in the profits garnered by the price fixers. Even in this so-called "clean" case, can we be certain that direct purchasers will aggressively pursue legal action? In cases that they cannot pass on the overcharge, it would seem likely but with possible exceptions. In cases that the overcharge can easily be passed-on, the probabilities likely drop. This may seem counterintuitive. In both cases-no or little pass-on or full pass-on-it appears to be in the profit maximizing interest of the firm to pursue the maximum expected recovery possible. This raises two related questions. First, do firms take advantage of every profit maximizing opportunity? Second, are firms that pass on most or all of the overcharge rather easily likely to feel as "damaged" or as "wronged" as firms that are unable to pass on the overcharge?

Both of these questions seem awkward because they raise issues of how firms behave and or what might be called the "psychology" of business decisions. Whether firms seek solely to maximize profits has been a long-standing area of debate. ${ }^{308}$ In theory, a corporation that is under performing is ripe for a takeover by those who see the potential for increased profit. This obviously raises principal-agent issues-just how much do the utility functions of those who manage firms deviate from the goals of shareholders? Even if one thinks the deviation between the goals of

306 Richman \& Murray, supra note 10, at 94-95.

307 Id. at 95 n.118 and accompanying text; see also Schinkel et al., supra note 10 , at 684 .

308 See generally Adamantios Diamantopoulos \& Brian P. Mathews, The Specification of Pricing Objectives: Empirical Evidence for Oligopoly Firm, 15 MANAGERIAL \& DECISION ECON. 73 (1994); George W. England \& Raymond Lee, Organizational Goals and Expected Behavior Among American, Japanese, and Korean Managers-A Comparative Study, 14 ACAD. OF MGMT. J. 425 (1971); H.T. Koplin The Profit Maximization Assumption, 15 OxFORD ECON. PAPERS 130 (1963); Anant K. Sundaram \& Andrew C. Inkpen, The Corporate Objective Revisited, 15 ORGANIZATIONAL SCI. 350 (2004). 
management and shareholders is rare and narrow, that does not solve the problem.

Although impossible to verify as an empirical matter, there is no doubt that many direct purchasers are not corporations. When management and ownership merge, the preference of management for lower stress, leisure time, and an aversion to confrontation may result in avoiding legal action, even when the expected monetary value is positive. Although it is conjecture, behavior may change, especially for the manager/owner when overcharges are easily passed-on. When they are not passed-on the result is a decrease in profit. When they are passed-on, profits remain the same and there may be little incentive to litigate over what may be perceived as a windfall.

\section{CONCLUSIONS AND RECOMMENDATIONS}

Antitrust policy is largely shaped by the desire to balance the problems of false positives and false negatives. False positives occur when a harmless or pro-competitive activity is found to violate the antitrust laws. ${ }^{309}$ False negatives are obviously the opposite. ${ }^{310}$ The problem is particularly severe in antitrust because most activities are assessed under the rule of reason, which is by no means a bright-line test. ${ }^{311}$ The continued application of Illinois Brick is best assessed in terms of whether it increases the likelihood of errors of either type.

The possibility that loosening the reins of Illinois Brick in the current era of antitrust would result in greater error rates is exceedingly slim. This Article explains why. Antitrust law has changed dramatically since 1977. ${ }^{312}$ The substantive law has shifted to be highly protective of defendants. ${ }^{313}$ Success for a plaintiff in a rule of reason case is rare. ${ }^{314}$ Procedural changes relating to pleading and class certification have also raised barriers to plaintiffs. ${ }^{315}$ Standards have also been raised with respect to expert

\footnotetext{
${ }^{309}$ Barnett, supra note 9 and accompanying text.

310 See id.

311 See supra text accompanying notes $232-40$.

312 Supra text accompanying notes 74-75.

313 See supra Section II.B.

314 Supra text accompanying notes 242-48.

315 See supra text accompanying notes 249-67, 280-95.
} 
testimony that make it unlikely that any but the most well developed damages theories will be admitted into evidence. ${ }^{316}$ Finally, Apple v. Pepper reveals a sharp division in the Court on the issue of what Illinois Brick means. ${ }^{317}$ In sum, whatever role Illinois Brick may have ever played in rationalizing antitrust law is now unneeded, and the recent decision by the Court illustrates that, after forty years, a consensus is lacking on what it stands for. ${ }^{318}$

The question then becomes what adjustments should be made. This Article closes with three possibilities.

1. The first and least complicated is simply to overturn Illinois Brick. Yes, this will invite more litigation by indirect purchasers, but, given the documented reluctance of direct purchasers to pursue actions, this may be necessary. The concern about multiple liability noted by the Court in Illinois Brick is overstated. 319 Each indirect purchaser should be limited to a recovery equal to the amount by which it was actually damaged-not a portion of the overcharge. A corollary to this is that direct purchasers would also be entitled to the amount by which they were damaged. As noted earlier, the Court's decision to adopt the overcharge measure of damages in price fixing cases but not in others was not well-founded. Restricting plaintiffs to lost profits means that there is no danger of duplicative recoveries and that Hanover Shoe also becomes obsolete.

2. A second approach involves a slight reinterpretation of Associated General Contractors. It will be recalled that the Court weighs a variety of factors in its standing analysis. ${ }^{320}$ One of those factors - direct purchasinghas become a required factor. ${ }^{321}$ An approach that would alleviate the harshness of Illinois Brick would be to simply make directness of the injury one of the factors to be weighed against the others. In short,

\footnotetext{
316 See supra text accompanying notes 268-79.

317 See supra Section II.A.2.

318 See supra text accompanying note 146.

319 See supra text accompanying notes 296-97.

320 See supra text accompanying notes 86-95.

321 See supra text accompanying notes 90-92.
} 
732 WILLIAM \& MARY BUSINESS LAW REVIEW [Vol. 11:695

directness would no longer be necessary in order for an antitrust plaintiff to have standing. Interestingly this is arguably consistent with a careful reading of Associated General Contractors. ${ }^{322}$

3. The third approach would be the most difficult for the Court to implement. It would provide an Illinois Brick exemption for indirect purchasers in cases in which substantial direct purchaser action has not been brought within a specified period of time. ${ }^{323}$ For example, if three years after the cause of action accrues, the direct purchasers had not filed an action, the Illinois Brick "gate" would open for indirect purchasers. Realistically, it is difficult to imagine this exemption as resulting from judicial action. It would require the unlikely event of a case making it to the Supreme Court in which such an exemption was applied by a lower court. If this proposal were adopted, it seems more likely to be the result of legislative action.

322 See supra text accompanying notes 91-99.

${ }^{323}$ A similar approach was advanced by the Ninth Circuit Court of Appeals, Freeman v. San Diego Ass'n of Realtors, 322 F.3d 1133, 1145-46 (9th Cir. 2003). 